\title{
Growth, mineral composition, fruit yield, and mycorrhizal colonization of feijoa in response to lime and phosphorus application
}

\author{
Gilberto Nava(1), Karine Louise dos Santos ${ }^{(2)}$, Murilo Dalla Costa ${ }^{(3)}$ and Marlise Nara Ciotta ${ }^{(4)}$ \\ (1)Embrapa Clima Temperado, BR-392, Km 78, $9^{\circ}$ Distrito, Monte Bonito, Caixa Postal 403, CEP 96010-970 Pelotas, RS, Brazil. E-mail: \\ gilberto.nava@embrapa.br (2)Universidade Federal de Santa Catarina, Centro de Ciências Rurais, Rodovia Ulysses Gaboardi, Km 3, \\ Campus de Curitibanos, Caixa Postal 101, CEP 89520-000 Curitibanos, SC, Brazil. E-mail: karine.santos@ufsc.br ${ }^{(3)}$ Empresa de Pesquisa \\ Agropecuária e Extensão Rural de Santa Catarina (Epagri), Estação Experimental de Lages, Rua João José Godinho, s/nº, Morro do Posto, \\ CEP 88502-970 Lages, SC, Brazil. E-mail: murilodc@epagri.sc.gov.br (4)Epagri, Estação Experimental de São Joaquim, Rua João Araújo \\ Lima, no 102, Jardim Caiçara, CEP 88600-000 São Joaquim, SC, Brazil. E-mail: marlise@epagri.sc.gov.br
}

\begin{abstract}
The objective of this work was to investigate the effect of liming and phosphorus fertilization on the growth, mineral composition of the leaves, fruit yield, and mycorrhizal colonization of young feijoa (Acca sellowiana) plants. Treatments consisted of four liming levels $-0,25,50$, and $100 \%$ of the dose required to raise the soil pH to 6.5 - and of five levels of $\mathrm{P}-0,60,120,180$, and $240 \mathrm{~kg} \mathrm{ha}^{-1} \mathrm{P}_{2} \mathrm{O}_{5}-$, placed in a randomized complete block design, in a split-plot arrangement, with three replicates. The orchard was established in 2010 with the Helena cultivar. In 2012, 2013, and 2014, plant growth was evaluated by measuring trunk perimeter, plant height, and tree canopy width. Mineral composition of the leaves, regarding P, N, K, Ca, and Mg contents, was assessed annually. Mycorrhizal colonization was evaluated in 2012, and fruit yield was determined in 2014. No interaction was observed between the studied factors. P contents had no effect on the evaluated variables. Liming, however, increases plant growth, mycorrhizal colonization, fruit yield, and $\mathrm{Ca}$ and $\mathrm{Mg}$ leaf contents, besides reducing $\mathrm{K}$ leaf contents.
\end{abstract}

Index terms: Acca sellowiana, mineral nutrition, mycorrhizal colonization, nutritional status, phosphorus fertilization, soil acidity.

\section{Crescimento, composição mineral, produção e colonização micorrízica de goiabeira serrana em resposta à aplicação de calcário e fósforo}

\begin{abstract}
Resumo - O objetivo deste trabalho foi avaliar o efeito da calagem e da adubação fosfatada no crescimento, na composição mineral das folhas, na produção de frutos e na colonização micorrízica de plantas jovens de goiabeira serrana (Acca sellowiana). Os tratamentos consistiram de quatro níveis de calagem - 0, 25, 50 e $100 \%$ da dose necessária para elevar o $\mathrm{pH}$ do solo a 6,5 - e de cinco níveis de fósforo $-0,60,120,180 \mathrm{e}$ $240 \mathrm{~kg} \mathrm{ha}^{-1} \mathrm{de}_{2} \mathrm{O}_{5}$-, dispostos em delineamento de blocos ao acaso, em arranjo de parcelas subdivididas, com três repetições. O pomar foi implantado em 2010 com a cultivar Helena. Em 2012, 2013 e 2014, o crescimento das plantas foi avaliado por meio da medição do perímetro do tronco, da altura das plantas e do diâmetro das copas. A composição mineral das folhas, quanto aos teores de $\mathrm{P}, \mathrm{N}, \mathrm{K}, \mathrm{Ca}$ e $\mathrm{Mg}$, foi avaliada anualmente. A colonização micorrízica foi avaliada em 2012, e a produção de frutos foi determinada em 2014. Não houve interação entre os fatores estudados. Os níveis de P não tiveram efeito sobre as variáveis avaliadas. A calagem, no entanto, aumenta o crescimento das plantas, a colonização micorrízica, a produção de frutos e os teores foliares de $\mathrm{Ca}$ e $\mathrm{Mg}$, além de ter reduzido o teor foliar de $\mathrm{K}$.
\end{abstract}

Termos para indexação: Acca sellowiana, nutrição mineral, colonização micorrízica, estado nutricional, adubação fosfatada, acidez do solo.

\section{Introduction}

Feijoa [Acca sellowiana (Berg.) Burret (Syn. Feijoa sellowiana Berg.)] is a plant species of the family Myrtaceae, native to the southern Brazilian plateau, northeastern Uruguay (Mattos, 1986), and Argentina (Keller \& Tressens, 2007). Its fruits have excellent organoleptic potential for sale in natura (Barni et al., 2004) and they can be processed as juices, jellies, ice cream, and liqueurs (Thorp \& Bieleski, 2002), besides having pharmacological properties (Vuotto et al., 2000).

New Zealand and Colombia are the major producers and exporters of the fruit. Although the largest natural 
concentration of this species occurs in Brazil, the country imports most fruits from Colombia, where local population considers the species native.

The lack of proper cultural practices for the management of this culture, such as the absence of a fertilization recommendation system adjusted to the soil and climatic conditions where feijoa adapts to in Brazil, are factors that limit the culture's productivity and expansion in the country. Moreover, research on the nutritional management of this culture is scarce, which makes recommendations for fertilizing and liming more difficult, either before or after the planting of seedlings.

In Brazil, soils where the species occurs are usually acidic, with high contents of exchangeable $\mathrm{Al}$ and low contents of extractable P. However, the best results for commercial production of the fruit are obtained in fertile, well-drained, slightly acidic ( $\mathrm{pH}$ 6.0-6.5) soils, with high organic matter (OM) contents (Thorp $\&$ Bieleski, 2002; Fisher et al., 2003). Studies on plants grown in pots showed positive effects of liming and phosphate fertilization on feijoa growth (Dal Bó \& Ducroquet, 1992). However, works carried out under field conditions are still essential for a better adjustment of fertilization recommendations.

The objective of this work was to investigate the effect of liming and phosphorus fertilization on the growth, mineral composition of the leaves, fruit yield, and mycorrhizal colonization of young feijoa (Acca sellowiana) plants.

\section{Materials and Methods}

The experiment was conducted at the experimental station of Empresa de Pesquisa Agropecuária e Extensão Rural de Santa Catarina (Epagri), in the municipality of São Joaquim, in the state of Santa Catarina, Brazil $\left(28^{\circ} 17^{\prime} 25^{\prime \prime} \mathrm{S}, 4^{\circ} 56^{\prime} 56^{\prime \prime} \mathrm{W}\right.$, at an altitude of $\left.1,415 \mathrm{~m}\right)$. The orchard was planted in 2010, with the cultivar Helena, obtained from the breeding program of Epagri.

The soil of the experimental area is classified as a Cambissolo Húmico (Santos et al., 2013), i.e., an Inceptisol, with the following physicochemical attributes: $\mathrm{pH}$ in $\mathrm{H}_{2} \mathrm{O}$ of $5.1 ; 4.2 \mathrm{mg} \mathrm{dm}^{-3} \mathrm{P}$; $2.51 \mathrm{mmol}_{\mathrm{c}} \mathrm{dm}^{-3} \mathrm{~K} ; 17 \mathrm{mmol}_{\mathrm{c}} \mathrm{dm}^{-3} \mathrm{Ca} ; 8 \mathrm{mmol}_{\mathrm{c}} \mathrm{dm}^{-3}$ $\mathrm{Mg} ; 69 \mathrm{~g} \mathrm{dm}^{-3} \mathrm{OM}$; and $250 \mathrm{~g} \mathrm{dm}^{-3}$ clay.

The treatments were placed in a randomized complete block design, in a split-plot arrangement, with three replicates. The main plots $(30 \times 4.0 \mathrm{~m})$ received four liming doses: $0,25,50$, and $100 \%$ of the dose required to raise the $\mathrm{pH}$ in $\mathrm{H}_{2} \mathrm{O}$ to 6.5 , which corresponded to 0 , 12,24 , and $36 \mathrm{Mg} \mathrm{ha}^{-1}$, respectively; and the split-plots $(6.0 \times 4.0 \mathrm{~m})$ received five doses of P: $0,60,120,180$, and $240 \mathrm{~kg} \mathrm{ha}^{-1} \mathrm{P}_{2} \mathrm{O}_{5}$. Dolomitic lime was applied in two equal doses and incorporated into the soil through a sequence of plowing and harrowing operations, up to about $0.40-\mathrm{m}$ depth. $\mathrm{P}$ doses, in the form of triple superphosphate, were incorporated into the soil along with the second lime application.

To favor the early development of the plant, the flowers developed until the 2012/2013 crop season were removed. Annually, in November and January, surface $\mathrm{N}$ fertilization $\left(30 \mathrm{~kg} \mathrm{ha}^{-1} \mathrm{~N}\right)$ was performed. In 2012, 2013, and 2014, plant growth was evaluated by measuring trunk perimeter, plant height, and canopy width. Additionally, the first fruit yield was assessed in 2014.

Also annually, in the second fortnight of March, 40 leaf samples were sampled from the median portion of the branches grown during the year, at the median height of the plant. The leaves were dried at $65^{\circ} \mathrm{C}$ and ground afterward. Subsamples of $0.5 \mathrm{~g}$ of the ground material were subjected to nitric-perchloric acid digestion with $1.0 \mathrm{~mL} \mathrm{HClO}_{4}+6.0 \mathrm{~mL} \mathrm{HNO}_{3}$, at $190^{\circ} \mathrm{C}$, in a digester block. In the extract, $\mathrm{P}$ contents were determined by UV spectrophotometry through the vanadate-molybdate method; and $\mathrm{K}, \mathrm{Ca}$, and $\mathrm{Mg}$ contents, by flame atomic absorption spectrometry. $\mathrm{N}$ was obtained by the micro-Kjeldahl method after digestion of $0.2 \mathrm{~g}$ with $2.0 \mathrm{~mL} \mathrm{H}_{2} \mathrm{O}_{2}+5.0 \mathrm{~mL} \mathrm{H}_{2} \mathrm{SO}_{4}$ and catalyst salts at $380^{\circ} \mathrm{C}$.

In March 2012, samples of the root system, i.e., root fragments of approximately $1.0 \mathrm{~g}$, were randomly collected in the canopy projection area. The intensity of the mycorrhizal colonization in the root system and the arbuscule abundance in mycorrhizal parts of root fragments were determined and calculated as described by Trouvelot et al. (1986). For this analysis, root fragments were: preserved in alcohol $50 \%$; subjected to discoloration with $\mathrm{KOH} 10 \%$ for 24 hours, at room temperature, and for $35 \mathrm{~min}$, at $121^{\circ} \mathrm{C}$; and then subjected to coloration with glycerol acid solution containing $0.05 \%$ trypan blue, at $121^{\circ} \mathrm{C}$, for $10 \mathrm{~min}$ (Koske \& Gemma, 1989).

Pesq. agropec. bras., Brasília, v.51, n.8, p.942-949, ago. 2016 DOI: 10.1590/S0100-204X2016000800006 
The results were subjected to the analysis of variance, at $5 \%$ probability, and to the regression analysis to determine the effects of $\mathrm{P}$ and lime doses.

\section{Results and Discussion}

The effects of lime and $\mathrm{P}$ doses did not interact with each other. Phosphorus application had no effect on any of the evaluated variables, except canopy width. However, lime had a significant effect on all of them, increasing trunk perimeter, plant height, and canopy width (Table 1). These results indicate that, although feijoa is adapted to acidic soils, liming improves plant growth in the period preceding production, as reported by Dal Bó \& Ducroquet (1992) for plants grown in pots.

Table 1. Plant growth parameters of feijoa (Acca sellowiana) in response to the application of different lime doses to the soil in 2012, 2013, and 2014.

\begin{tabular}{|c|c|c|c|}
\hline \multirow{2}{*}{$\begin{array}{l}\text { Lime dose } \\
\left(\mathrm{Mg} \mathrm{ha}^{-1}\right)^{(1)}\end{array}$} & Trunk perimeter & Plant height & Canopy width \\
\hline & \multicolumn{3}{|c|}{--------------------------------(cm)--------------------------------- } \\
\hline & \multicolumn{3}{|c|}{$2012^{(2)}$} \\
\hline 0 & $6.8^{*}$ & $100^{*}$ & $42 *$ \\
\hline 12 & 8.2 & 109 & 52 \\
\hline 24 & 8.2 & 107 & 52 \\
\hline 36 & 9.1 & 112 & 57 \\
\hline \multirow[t]{2}{*}{ CV $(\%)$} & 16.0 & 10.2 & 27.5 \\
\hline & \multicolumn{3}{|c|}{$2013^{(3)}$} \\
\hline 0 & $24.8^{*}$ & $123^{*}$ & $96^{*}$ \\
\hline 12 & 31.6 & 148 & 121 \\
\hline 24 & 31.6 & 144 & 119 \\
\hline 36 & 33.0 & 142 & 123 \\
\hline \multirow[t]{2}{*}{ CV (\%) } & 16.0 & 16.9 & 16.1 \\
\hline & \multicolumn{3}{|c|}{$2014^{(4)}$} \\
\hline 0 & $37.3^{*}$ & $136^{*}$ & $136^{*}$ \\
\hline 12 & 46.8 & 166 & 164 \\
\hline 24 & 45.3 & 153 & 155 \\
\hline 36 & 46.7 & 166 & 160 \\
\hline $\begin{array}{l}\mathrm{CV}(\%) \\
\end{array}$ & 13.2 & 13.5 & 11.2 \\
\hline
\end{tabular}

(1) Lime doses respectively associated with $0,25,50$, and $100 \%$ of the required dose necessary to increase soil $\mathrm{pH}$ to 6.5 . ${ }^{(2)}$ Significant regressions associated with: trunk perimeter, $\mathrm{y}=7.04+0.0575 \mathrm{x}\left(\mathrm{R}^{2}=0.88\right)$; plant height, $\mathrm{y}=100.9+0.533 \mathrm{x}-0.0069 \mathrm{x}^{2}\left(\mathrm{R}^{2}=0.79\right)$; and canopy width, $\mathrm{y}=42.75+0.687 \mathrm{x}-0.0087 \mathrm{x}^{2}\left(\mathrm{R}^{2}=0.90\right) .{ }^{(3)}$ Significant regressions associated with: trunk perimeter, $\mathrm{y}=25.21+0.542 \mathrm{x}-0.0094 \mathrm{x}^{2}\left(\mathrm{R}^{2}=0.92\right)$; plant height, $\mathrm{y}=124.55+2.129 \mathrm{x}-0.0468 \mathrm{x}^{2}\left(\mathrm{R}^{2}=0.87\right)$; and canopy width, $y=97.65+1.9708 x-0.0365 x^{2}\left(R^{2}=0.86\right) .{ }^{(4)}$ Significant regressions associated with: trunk perimeter, $\mathrm{y}=37.99+0.7287 \mathrm{x}-0.0141 \mathrm{x}^{2}\left(\mathrm{R}^{2}=0.84\right)$; plant height, $\mathrm{y}=139.45+1.7042 \mathrm{x}-0.02951 \mathrm{x}^{2}\left(\mathrm{R}^{2}=0.61\right)$; and canopy width, $\mathrm{y}=138.55+1.9625 \mathrm{x}-0.0399 \mathrm{x}^{2}\left(\mathrm{R}^{2}=0.72\right) . \mathrm{CV}$, coefficient of variation. *Significant regressions at $5 \%$ probability.
The positive effect of liming for plants, in general, has been known for a long time. The application of lime to acidic soils promotes greater development of the plant root system, consequently improving water and nutrient absorption. Besides neutralizing the toxic forms of $\mathrm{Al}$ (Kochian et al., 2005), liming also supplies $\mathrm{Ca}$, which has a preponderant role in root growth. Ca uptake occurs only in newer parts of the roots, not yet suberized (Marschner, 2012); therefore, it requires continuous absorption to ensure the adequate development of the root system (Tagliavini \& Scandellari, 2013), since new roots are only formed when the nutrient is present in the soil (Taiz \& Zeiger, 2013).

As previously mentioned, phosphorus $\mathrm{P}$ fertilization did not affect any of the evaluated variables, except canopy width in 2013 (Table 2). This result may be related to the fact that fruit trees generally show little response to this nutrient, whose absorption is relatively lower than that of other macronutrients, such as $\mathrm{N}$ and

Table 2. Growth parameters of feijoa (Acca sellowiana) in response to the application of different phosphorous doses to the soil in 2012, 2013, and 2014.

\begin{tabular}{|c|c|c|c|}
\hline \multirow{3}{*}{$\begin{array}{l}\mathrm{P}_{2} \mathrm{O}_{5} \\
\left(\mathrm{~kg} \mathrm{ha}^{-1}\right)\end{array}$} & Trunk perimeter & Height & Canopy width \\
\hline & \multicolumn{3}{|c|}{ 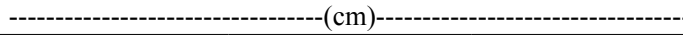 } \\
\hline & \multicolumn{3}{|c|}{2012} \\
\hline 0 & 7.87 & 106 & 46 \\
\hline 60 & 8.12 & 110 & 50 \\
\hline 120 & 7.96 & 108 & 51 \\
\hline 180 & 8.42 & 107 & 52 \\
\hline$\underline{240}$ & 8.00 & 104 & 55 \\
\hline \multirow[t]{2}{*}{ CV (\%) } & 16.0 & 10.2 & 27.5 \\
\hline & \multicolumn{3}{|c|}{$2013^{(1)}$} \\
\hline 0 & 30.5 & 143 & $115.0^{*}$ \\
\hline 60 & 30.4 & 142 & 114.2 \\
\hline 120 & 29.7 & 130 & 112.2 \\
\hline 180 & 30.3 & 138 & 113.6 \\
\hline 240 & 31.8 & 149 & 125.5 \\
\hline \multirow[t]{2}{*}{ CV (\%) } & 16.0 & 16.9 & 16.1 \\
\hline & \multicolumn{3}{|c|}{2014} \\
\hline 0 & 43.7 & 157 & 155 \\
\hline 60 & 43.0 & 149 & 148 \\
\hline 120 & 43.0 & 154 & 156 \\
\hline 180 & 44.1 & 154 & 153 \\
\hline$\underline{240}$ & 46.3 & 160 & 155 \\
\hline CV (\%) & 13.2 & 13.5 & 11.2 \\
\hline
\end{tabular}

${ }^{(1)}$ Significant regression associated with canopy width: $y=115.23-0.1892 \mathrm{x}$ $+0.0038 \mathrm{x}^{2}\left(\mathrm{R}^{2}=0.75\right) . \mathrm{CV}$, coefficient of variation. *Significant regression at $5 \%$ probability. 
K (Neilsen et al., 2008). Furthermore, compared with annual crops, fruit trees have greater time for nutrient uptake, which favors the accumulation of reserves, requiring lower amounts of available P. In addition, the high $\mathrm{OM}$ content in the soils of the studied region probably contributed to significantly increase $\mathrm{P}$ availability for feijoa. Another factor that greatly contributes to increase $\mathrm{P}$ uptake is the association of roots with arbuscular mycorrhizal fungi (Cardoso \& Kuyper, 2006), which may also be related to the efficiency of P use by the trees. In the present study, water stresses may also have limited the response to $\mathrm{P}$, since the experimental area was not irrigated and the main supply route of $\mathrm{P}$ to the roots, i.e., diffusion, is a mechanism highly dependent on soil moisture content (Santos et al., 2008).

In another study, however Dal Bó \& Ducroquet (1992) observed that feijoa growth responded to phosphate fertilization. This positive response was probably linked to the different $\mathrm{P}$ availability in the evaluated soils and the smaller soil volume for exploration by the plants, which were grown in pots in their experiment.

With respect to the mineral composition of the leaves, the greater plant growth promoted by liming was accompanied by increased $\mathrm{Ca}$ and $\mathrm{Mg}$ leaf contents, which approximately doubled with the application of any of the lime doses (Table 3). Because dolomitic lime contains $\mathrm{Ca}$ and $\mathrm{Mg}$ in its composition, it increases the availability of these nutrients in the soil solution, favoring their uptake by the plants. Lime application also affects indirectly $\mathrm{N}$ availability, since it promotes increased microbial activity and, consequently, greater $\mathrm{OM}$ mineralization rate, which is a major $\mathrm{N}$ source to plants. This effect can explain the increased foliar $\mathrm{N}$ content in the first year when liming was used.

Regardless of the year, $\mathrm{K}$ leaf contents were reduced with lime application (Table 3 ). The lower K contents in the leaves can be associated with the nutrient dilution effect in response to increased plant growth in the presence of lime. Liming also increases the number of negative charges (CEC) in the soils (Havlin et al., 2013), which favors $K$ adsorption in the new charges generated by liming (Ernani, 2008), reducing K activity in the soil solution.

Beyhan et al. (2011) evaluated nutrient contents in feijoa leaves and found significant variations between the genotypes studied. According to the authors, the N,
$\mathrm{P}, \mathrm{K}, \mathrm{Ca}$, and $\mathrm{Mg}$ contents ranged from 14.2-22.2 for N, 0.86-1.34 for P, 3.6-6.6 for K, 1.7-3.4 for $\mathrm{Ca}$, and $0.19-3.20 \mathrm{mg} \mathrm{kg}^{-1}$ for $\mathrm{Mg}$, depending on the genotype. These results contrast with those obtained in the present study, especially in terms of $\mathrm{K}$ and $\mathrm{Ca}$ contents, which were lower and higher, respectively (Table 3). These discrepant contents can be attributed to the different soil types, climate, and genotypes analyzed in each experiment.

Regardless of the crop, none of the leaf nutrient contents, not even that of $\mathrm{P}$, changed in response to phosphate fertilization (Table 4). These results show that, in similar soils with high OM content, $\mathrm{P}$ is not a limiting nutrient for plant growth. However, further studies may indicate the need or not to use phosphate fertilizers during the full production cycle of this crop.

Since fruit yield did not respond to phosphate fertilization, it was not possible to establish the critical value of $\mathrm{P}$ between relative fruit yield and soil $\mathrm{P}$ content

Table 3. Leaf contents of N, P, K, Ca, and Mg in feijoa (Acca sellowiana) in response to the application of different lime doses to the soil in 2012, 2013, and 2014.

\begin{tabular}{|c|c|c|c|c|c|}
\hline \multirow{3}{*}{$\begin{array}{l}\text { Lime dose }{ }^{(1)} \\
\left(\mathrm{Mg} \mathrm{ha}^{-1}\right)\end{array}$} & \multicolumn{5}{|c|}{ Mineral composition of the leaves } \\
\hline & $\mathrm{N}$ & $\mathrm{P}$ & $\mathrm{K}$ & $\mathrm{Ca}$ & $\mathrm{Mg}$ \\
\hline & \multicolumn{5}{|c|}{ 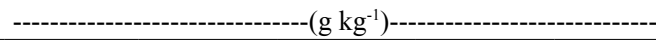 } \\
\hline & \multicolumn{5}{|c|}{$2012^{(2)}$} \\
\hline 0 & $15.3 *$ & 1.48 & $16.5^{*}$ & $2.99 *$ & $1.18^{*}$ \\
\hline 12 & 15.7 & 1.28 & 10.7 & 6.08 & 2.18 \\
\hline 24 & 16.4 & 1.34 & 11.0 & 6.61 & 2.35 \\
\hline \multirow[t]{2}{*}{36} & 16.8 & 1.30 & 10.5 & 6.61 & 2.32 \\
\hline & \multicolumn{5}{|c|}{$2013^{(3)}$} \\
\hline 0 & 18.8 & $1.45^{*}$ & $10.9^{*}$ & $4.15^{*}$ & $1.27 *$ \\
\hline 12 & 19.2 & 1.56 & 9.0 & 7.78 & 2.51 \\
\hline 24 & 19.5 & 1.70 & 8.8 & 8.09 & 2.75 \\
\hline \multirow[t]{2}{*}{36} & 19.2 & 1.55 & 8.1 & 9.15 & 2.90 \\
\hline & \multicolumn{5}{|c|}{$2014^{(4)}$} \\
\hline 0 & 23.5 & 1.99 & $11.3 *$ & $5.00 *$ & $1.50 *$ \\
\hline 12 & 22.5 & 2.06 & 8.9 & 7.95 & 3.00 \\
\hline 24 & 23.1 & 2.24 & 8.8 & 8.45 & 3.00 \\
\hline 36 & 21.8 & 2.00 & 7.0 & 9.14 & 3.10 \\
\hline
\end{tabular}

${ }^{(1)}$ Lime doses respectively associated with $0,25,50$, and $100 \%$ of the required dose necessary to increase soil $\mathrm{pH}$ to $6.5 .{ }^{(2)}$ Significant regressions associated with: $\mathrm{N}, \mathrm{y}=15.27+0.0433 \mathrm{x}\left(\mathrm{R}^{2}=0.98\right) ; \mathrm{K}, \mathrm{y}=16.155-0.4788 \mathrm{x}$ $+0.0092 \mathrm{x}^{2}\left(\mathrm{R}^{2}=0.90\right) ; \mathrm{Ca}, \mathrm{y}=3.0915+0.288 \mathrm{x}-0.0054 \mathrm{x}^{2}\left(\mathrm{R}^{2}=0.97\right) ;$ and $\mathrm{Mg}, 1.2115+0.0943 \mathrm{x}-0.0018 \mathrm{x}^{2}\left(\mathrm{R}^{2}=0.98\right) .{ }^{(3)}$ Significant regressions associated with: $\mathrm{P}, \mathrm{y}=1.434+0.0199 \mathrm{x}-0.0005 \mathrm{x}^{2}\left(\mathrm{R}^{2}=0.84\right) ; \mathrm{K}, \mathrm{y}=10.79$ $-0.1467 \mathrm{x}+0.0021 \mathrm{x}^{2}\left(\mathrm{R}^{2}=0.94\right) ; \mathrm{Ca}, \mathrm{y}=4.3535+0.2882 \mathrm{x}-0.0045 \mathrm{x}^{2}$ $\left(\mathrm{R}^{2}=0.94\right)$; and $\mathrm{Mg}, \mathrm{y}=1.3155+0.1109 \mathrm{x}-0.0019 \mathrm{x}^{2}\left(\mathrm{R}^{2}=0.97\right)$. ${ }^{(4)}$ Significantregressionsassociated with: $\mathrm{K}, \mathrm{y}=10.959-0.1083 \mathrm{x}\left(\mathrm{R}^{2}=0.90\right)$; Ca, $\mathrm{y}=5.132+0.2489 \mathrm{x}-0.0039 \mathrm{x}^{2}\left(\mathrm{R}^{2}=0.96\right) ;$ and $\mathrm{Mg}, \mathrm{y}=1.58+0.1275 \mathrm{x}-$ $0.0024 \mathrm{x}^{2}\left(\mathrm{R}^{2}=0.93\right)$. *Significant regression at $5 \%$ probability. 
in the 0.00-0.20-m layer, nor between the relative fruit yield and total $\mathrm{P}$ content in the leaves (Figure 1).

Lime application promoted significant increases in fruit yield and in the number of fruits per plant, in the first crop yield assessed (Figure 2). The application of $25 \%$ of the lime dose necessary for soil $\mathrm{pH}$ to reach 6.5 , in the $0.00-0.20-\mathrm{m}$ layer, increased it to 5.58 in 2013. This dose approximately doubled fruit yield compared with the plots that did not receive lime. The average mass of fruits $(103 \mathrm{~g})$ was similar between the treatments, indicating that the increase in yield can be attributed to the larger number of fruits per plant in the plots that had received lime, mainly in response to the increased availability of $\mathrm{Ca}$, which favors root and canopy growth. Critical values of $\mathrm{Ca}$ in the soil and in plant tissues related to the first fruit yield are shown in Figure 3. To reach $90 \%$ of the maximum yield, soil critical values should be $4.8 \mathrm{mg} \mathrm{dm}^{-3}$ of exchangeable $\mathrm{Ca}$, and $5.9 \mathrm{~g} \mathrm{~kg}^{-1}$ of total $\mathrm{Ca}$ in the leaves were obtained.

Since lime has low mobility in the soil when applied on soil surface (Ernani, 2008), in commercial crops, it should be applied and incorporated to the soil, prior to the planting of seedlings. This would enable greater initial plant growth, with positive effects on the productive capacity in subsequent years.

Table 4. Leaf contents of $\mathrm{N}, \mathrm{P}, \mathrm{K}, \mathrm{Ca}$, and $\mathrm{Mg}$ in feijoa (Acca sellowiana) in response to the application of different phosphorus doses to the soil in 2012, 2013, and 2014.

\begin{tabular}{|c|c|c|c|c|c|}
\hline \multirow{3}{*}{$\begin{array}{l}\text { Lime dose } \\
\left(\mathrm{Mg} \mathrm{ha}^{-1}\right)^{(1)}\end{array}$} & \multicolumn{5}{|c|}{ Mineral composition of the leaves } \\
\hline & $\mathrm{N}$ & $\mathrm{P}$ & $\mathrm{K}$ & $\mathrm{Ca}$ & $\mathrm{Mg}$ \\
\hline & \multicolumn{5}{|c|}{ 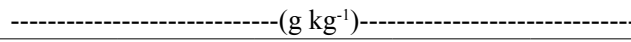 } \\
\hline & \multicolumn{5}{|c|}{2012} \\
\hline 0 & 16.6 & 1.39 & 12.6 & 5.58 & 2.01 \\
\hline 12 & 15.6 & 1.34 & 11.4 & 5.64 & 1.97 \\
\hline 24 & 15.7 & 1.34 & 12.1 & 5.78 & 2.04 \\
\hline \multirow[t]{2}{*}{36} & 16.4 & 1.32 & 12.3 & 5.22 & 1.97 \\
\hline & \multicolumn{5}{|c|}{2013} \\
\hline 0 & 19.3 & 1.58 & 9.4 & 7.39 & 2.35 \\
\hline 12 & 19.6 & 1.58 & 9.5 & 7.26 & 2.34 \\
\hline 24 & 18.6 & 1.59 & 9.1 & 7.48 & 2.44 \\
\hline \multirow[t]{2}{*}{36} & 19.1 & 1.52 & 8.9 & 7.10 & 2.34 \\
\hline & \multicolumn{5}{|c|}{2014} \\
\hline 0 & 21.5 & 2.08 & 9.2 & 8.05 & 2.88 \\
\hline 12 & 23.6 & 2.17 & 9.0 & 8.25 & 2.94 \\
\hline 24 & 23.1 & 2.20 & 9.0 & 8.30 & 2.94 \\
\hline 36 & 21.8 & 2.00 & 7.0 & 9.14 & 3.10 \\
\hline
\end{tabular}

The mycorrhizal colonization showed typical structures of arbuscular mycorrhizal fungi, as reported for A. sellowiana (Andrade et al., 2000), with intracellular hyphae and vesicles, and only arbuscules of the Arum-type (Berbara et al., 2006). Phosphorus doses had no effect on the colonization intensity of the root cortex, nor on the content of arbuscules (Figure 4). Although not confirmed in the present study, increased $\mathrm{P}$ availability in the soil commonly leads to decreased mycorrhizal colonization (Nogueira \& Cardoso, 2006; Balota et al., 2011; Smith et al., 2011). However, some tree species native to Brazil showed no decrease in mycorrhizal colonization due to increased $\mathrm{P}$ availability
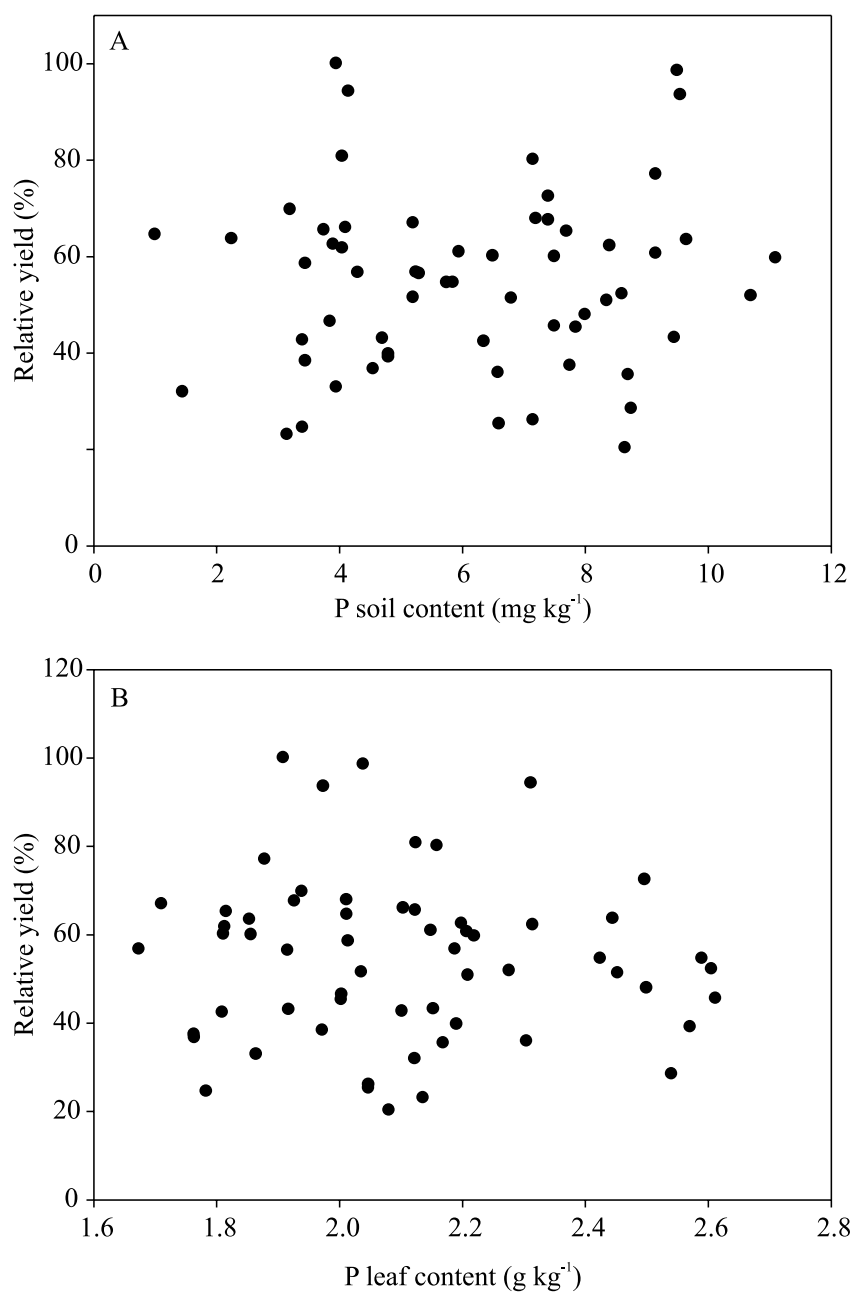

Figure 1. Relationship between: A, relative yield and available $\mathrm{P}$ content in the $0.00-0.20$ - $\mathrm{m}$ layer; and $\mathrm{B}$, relative yield and total $\mathrm{P}$ content in the leaves of feijoa (Acca sellowiana). Assessment performed in 2014. 


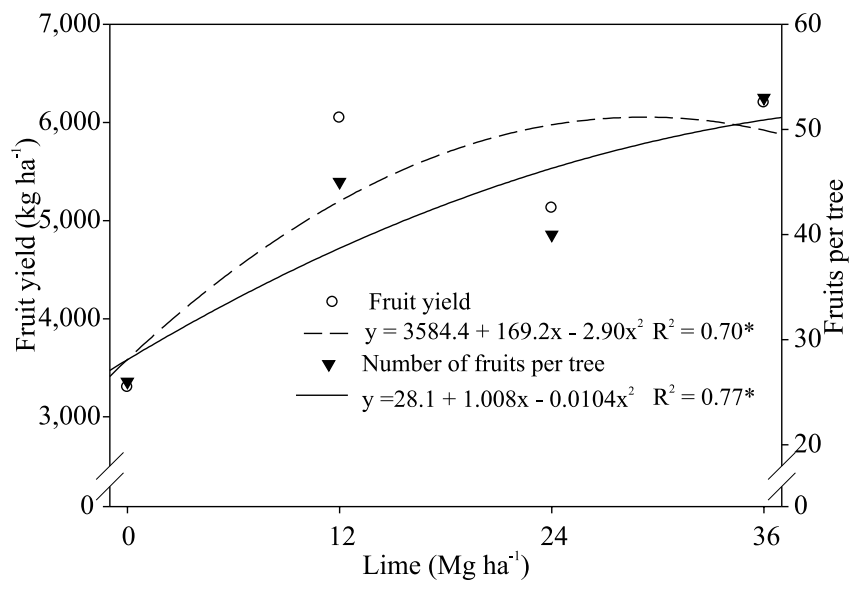

Figure 2. Yield and number of fruits of feijoa (Acca sellowiana) in response to the application of increasing lime doses to the soil. Assessment performed in 2014. *Significant at $5 \%$ probability.
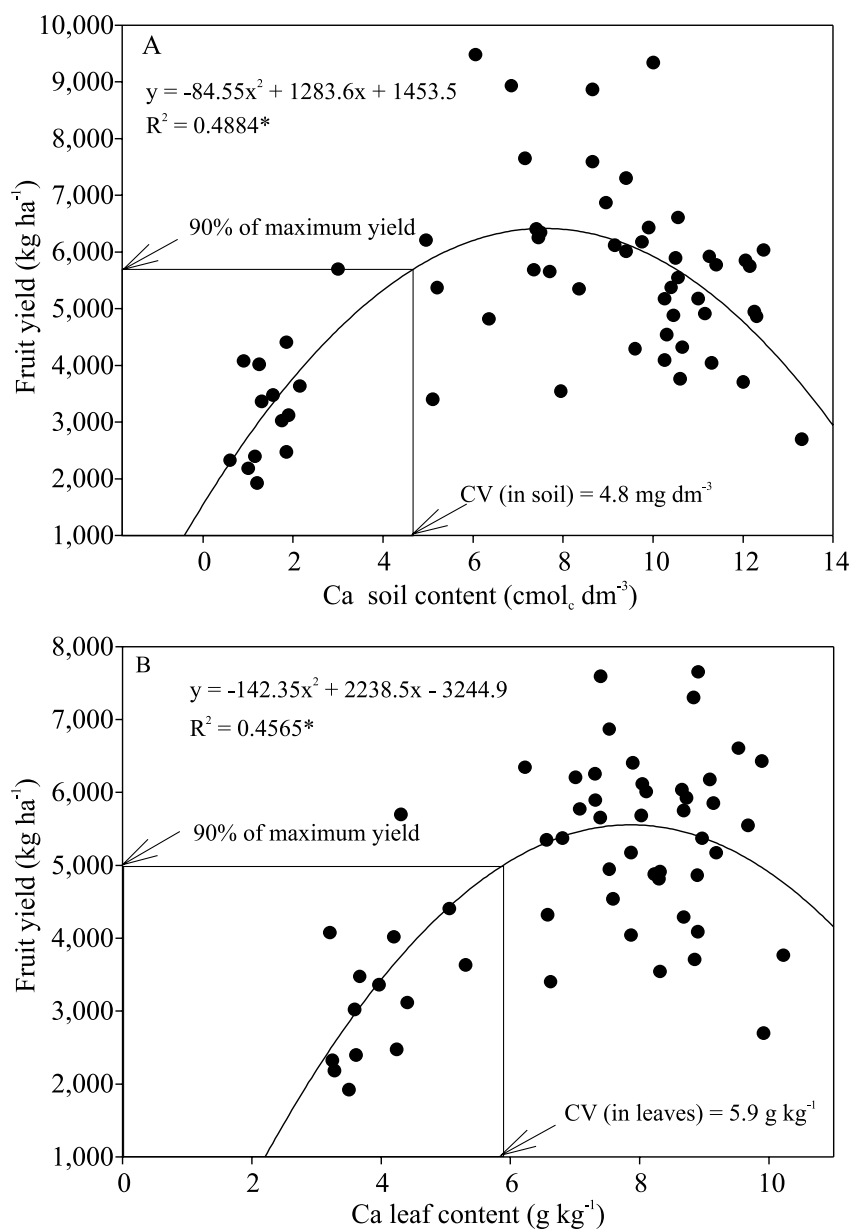

Figure 3. Relationship between: A, yield and exchangeable $\mathrm{Ca}$ content in the $0.00-0.20$-m layer; and $\mathrm{B}$, yield and total $\mathrm{Ca}$ content in the leaves of feijoa (Acca sellowiana). Assessment performed in 2014. *Significant at 5\% probability. CV, critical value. in the soil (Siqueira \& Saggin-Junior, 2001), which may be the case of $A$. sellowiana.

Similarly to the variables related to plant growth, mycorrhizal colonization was positively affected by lime application (Figure 4). Compared with the control, the application of the lowest lime dose increased colonization intensity by $60 \%$. Tolerance and sensitivity to acidity and to high levels of exchangeable $\mathrm{Al}$ in the soil vary between species and ecotypes of arbuscular mycorrhizal fungi, as well as between the stages of colonization (Seguel et al., 2013). Therefore, benefits to plant growth associated with mycorrhizal colonization can occur regardless of soil $\mathrm{pH}$, varying according to the species of mycorrhizal fungi (Cavallazzi et al., 2007). Other studies have also shown that lime application in the field can increase mycorrhizal colonization rates (Aliasgharzad et al., 2010; Schneider et al., 2011; Guo et al., 2012).

Increased availability of soil nutrients by raising soil $\mathrm{pH}$ and, at the same time, by supplying $\mathrm{Ca}$ and $\mathrm{Mg}$ through lime, provided improved plant nutrition, which may be related to increased mycorrhizal colonization rates in feijoa trees. Therefore, soil acidity should be corrected at the establishment of the orchard, and soil $\mathrm{pH}$ should be raised to at least 5.5, in order to ensure the elimination of the toxic effects of $\mathrm{Al}$ to the root system.

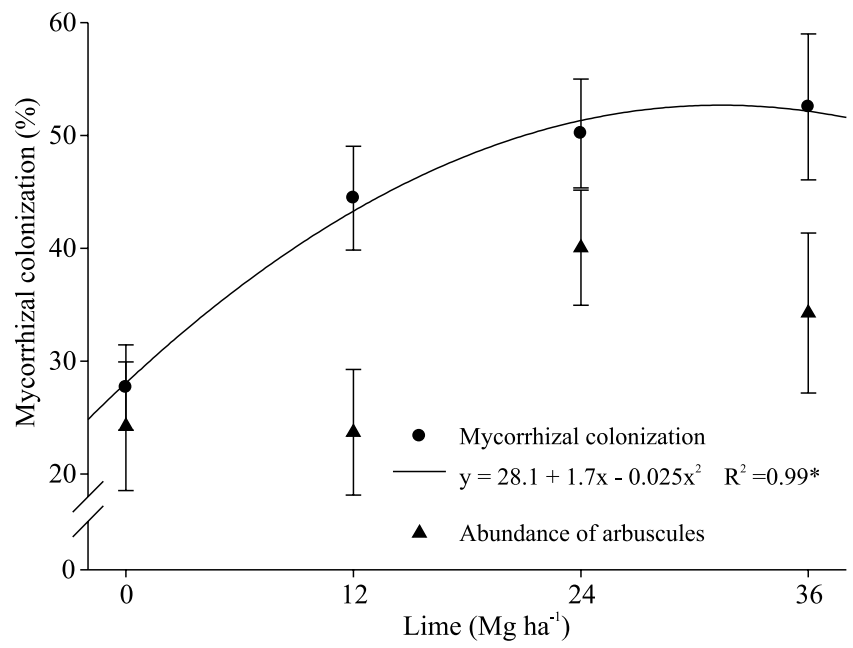

Figure 4. Intensity of the mycorrhizal colonization and arbuscule abundance in the mycorrhizal fraction (\%), in response to the application of increasing lime doses to the soil. Assessment performed in 2012. *Significant at 5\% probability.

Pesq. agropec. bras., Brasília, v.51, n.8, p.942-949, ago. 2016 DOI: $10.1590 / \mathrm{S} 0100-204 X 2016000800006$ 


\section{Conclusions}

1. Phosphate fertilization does not affect the mineral composition, growth, or fruit yield of feijoa (Acca sellowiana), which indicates that this culture is little responsive to the nutrient application in the early years of cultivation.

2. Soil liming improves the nutritional status, growth, fruit yield, and mycorrhizal colonization of feijoa.

\section{Acknowledgments}

To Empresa de Pesquisa Agropecuária e Extensão Rural de Santa Catarina (Epagri), for the experimental stations located at the municipalities of São Joaquim and Lages; and to Fundação de Amparo à Pesquisa do Estado de Santa Catarina (Fapesc) and to Conselho Nacional de Desenvolvimento Científico e Tecnológico (CNPq), for financial support.

\section{References}

ALIASGHARZAD, N.; MÅRTENSSON, L.-M.; OLSSON, P.A. Acidification of a sandy grassland favours bacteria and disfavours fungal saprotrophs as estimated by fatty acid profiling. Soil Biology and Biochemistry, v.42, p.1058-1064, 2010. DOI: 10.1016/j. soilbio.2010.02.025.

ANDRADE, A.C.S.; QUEIROZ, M.H.; HERMES, R.A.L.; OLIVEIRA, V.L. Mycorrhizal status of some plants of the Araucaria forest and the Atlantic rainforest in Santa Catarina, Brazil. Mycorrhiza, v.10, p.131-136, 2000. DOI: 10.1007/ s005720000070.

BALOTA, E.L.; MACHINESKI, O.; STENZEL, N.M.C. Resposta da acerola à inoculação de fungos micorrízicos arbusculares em solo com diferentes níveis de fósforo. Bragantia, v.70, p.166-175, 2011. DOI: $10.1590 /$ S0006-87052011000100023.

BARNI, E.J.; DUCROQUET, J.P.; SILVA, M.C.; BEPPLER NETO, R.; PRESSER, R.F. Potencial de mercado para goiabeiraserrana catarinense. Florianópolis: Epagri, 2004. 48p. (Epagri. Documentos, 212).

BERBARA, R.L.L.; SOUZA, F.A. de; FONSECA, H.M.A.C. Fungos micorrízicos arbusculares: muito além da nutrição. In: FERNANDES, M.S. (Ed.). Nutrição mineral de plantas. Viçosa: Sociedade Brasileira de Ciência do Solo, 2006. p.53-88.

BEYHAN, O.; BOZKURT, M.A.; BOYSAL, S.C. Determination of macro-micro nutrient contents in dried fruit and leaves and some pomological characteristics of selected feijoa genotypes (Feijoa sellowiana Berg.) from Sakarya provinces in Turkey. Journal of Animal and Plant Sciences, v.21, p.251-255, 2011.
CARDOSO, I.M.; KUYPER, T.W. Mycorrhizas and tropical soil fertility. Agriculture, Ecosystems \& Environment, v.116, p.72-84, 2006. DOI: 10.1016/j.agee.2006.03.011.

CAVALLAZZI, J.R.P.; KLAUBERG FILHO, O.; STÜRMER, S.L.; RYGIEWICZ, P.T.; MENDONÇA, M.M. de. Screening and selecting arbuscular mycorrhizal fungi for inoculating micropropagated apple rootstocks in acid soils. Plant Cell, Tissue and Organ Culture, v.90, p.117-129, 2007. DOI: 10.1007/ s11240-006-9163-6.

DAL BÓ, M.A.; DUCROQUET, J.-P.H.J. Efeito do pH e teor de P no solo sobre o crescimento e absorção de nutrientes da goiabeira serrana (Feijoa sellowiana). Revista Brasileira de Fruticultura, v.14, p.109-114, 1992.

ERNANI, P.R. Química do solo e disponibilidade de nutrientes. Lages: O Autor, 2008. 230p.

FISHER, G.; MIRANDA LASPRILLA, D.; CAYÓN SALINAS, G.; MAZORRA AGUDELO, M. (Ed.). Cultivo, poscosecha y exportación de la feijoa (Acca sellowiana Berg). Bogotá: Universidad Nacional de Colombia, 2003. 152p.

GUO, Y.J.; NI, Y.; RAMAN, H.; WILSON, B.A.L.; ASH, G.J.; WANG, A.S.; LI, G.D. Arbuscular mycorrhizal fungal diversity in perennial pastures; responses to long-term lime application. Plant and Soil, v.351, p.389-403, 2012. DOI: 10.1007/ s11104-011-0976-7.

HAVLIN, J.L.; TISDALE, S.L.; NELSON, W.L.; BEATON, J.D. Soil fertility and fertilizers. 8.ed. Upper Saddle River: Pearson, 2013. 528p.

KELLER, H.A.; TRESSENS, S.G. Presencia en Argentina de dos especies de uso múltiple: Acca sellowiana (Myrtaceae) y Casearia lasiophylla (Flacourtiaceae). Darwiniana, v.45, p.204-212, 2007.

KOCHIAN, L.V.; PIÑEROS, M.A.; HOEKENGA, O.A. The physiology, genetics and molecular biology of plant aluminum resistance and toxicity. Plant and Soil, v.274, p.175-195, 2005. DOI: $10.1007 / \mathrm{s} 11104-004-1158-7$

KOSKE, R.E.; GEMMA, J.N. A modified procedure for staining roots to detect VA mycorrhizas. Mycological Research, v.92, p.486-505, 1989. DOI: 10.1016/S0953-7562(89)80195-9.

MARSCHNER, P. (Ed.). Marschner's mineral nutrition of higher plants. 3.ed. London: Academic, 2012. 652p.

MATTOS, J.R. A goiabeira-serrana. Porto Alegre: Instituto de Pesquisas de Recursos Naturais Renováveis, 1986. 84p. (Publicação IPRNR, 19).

NEILSEN, G.H.; NEILSEN, D.; TOIVONEN, P.; HERBERT, L. Annual bloom-time phosphorus fertigation affects soil phosphorus, apple tree phosphorus nutrition, yield, and fruit quality. HortScience, v.43, p.885-890, 2008.

NOGUEIRA, M.A.; CARDOSO, E.J.B.N. Plant growth and phosphorus uptake in mycorrhizal rangpur lime seedlings under different levels of phosphorus. Pesquisa Agropecuária Brasileira, v.41, p.93-99, 2006. DOI: 10.1590/S0100-204X2006000100013.

SANTOS, D.R. dos; GATIBONI, L.C.; KAMINSKI, J. Fatores que afetam a disponibilidade do fósforo e o manejo da adubação 
fosfatada em solos sob sistema plantio direto. Ciência Rural, v.38, p.576-586, 2008.

SANTOS, H.G. dos; JACOMINE, P.K.T.; ANJOS, L.H.C. dos; OLIVEIRA, V.A. de; LUMBRERAS, J.F.; COELHO, M.R.; ALMEIDA, J.A. de; CUNHA, T.J.F.; OLIVEIRA, J.B. de. Sistema brasileiro de classificação de solos. 3.ed. rev. e ampl. Rio de Janeiro: Embrapa, 2013. 353p.

SCHNEIDER, J.; KLAUBERG FILHO, O.; FONTOURA, S.M.V.; ALVES, M.V. Influência de diferentes sistemas de manejo e calagem em experimento de longa duração sobre fungos micorrízicos arbusculares. Ciência e Agrotecnologia, v.35, p.701-709, 2011. DOI: $10.1590 / \mathrm{S} 1413-70542011000400008$.

SEGUEL, A.; CUMMING, J.R.; KLUGH-STEWART, K.; CORNEJO, P.; BORIE, F. The role of arbuscular mycorrhizas in decreasing aluminium phytotoxicity in acidic soils: a review. Mycorrhiza, v.23, p.167-183, 2013. DOI: 10.1007/ s00572-013-0479-x.

SIQUEIRA, J.O.; SAGGIN-JÚNIOR, O.J. Dependency on arbuscular mycorrhizal fungi and responsiveness of some Brazilian native woody species. Mycorrhiza, v.11, p.245-255, 2001. DOI: 10.1007/s005720100129.

SMITH, S.E.; JAKOBSEN, I.; GRØNLUND, M.; SMITH, F.A. Roles of arbuscular mycorrhizas in plant phosphorus nutrition: interactions between pathways of phosphorus uptake in arbuscular mycorrhizal roots have important implications for understanding and manipulating plant phosphorus acquisition. Plant Physiology, v.156, p.1050-1057, 2011. DOI: 10.1104/pp.111.174581.

TAGLIAVINI, M.; SCANDELLARI, F. Methodologies and concepts in the study of nutrient uptake requirements and partitioning in fruit trees. Acta Horticulturae, v.984, p.47-56, 2013. DOI: 10.17660/ActaHortic.2013.984.3.

TAIZ, L.; ZEIGER, E. Fisiologia vegetal. 5.ed. Porto Alegre: Artmed, 2013. 918p.

THORP, T.G.; BIELESKI, R.L. Feijoas: origins, cultivation and uses. Auckland: David Bateman, 2002. 87p.

TROUVELOT, A.; KOUGH, J.L.; GIANINAZZI-PEARSON, V. Mesure du taux de mycorhization VA d'un système radiculaire. Recherche de méthodes d'estimation ayant une signification fonctionnelle. In: GIANINAZZI-PEARSON, V:; GIANINAZZI, S. (Ed.). Mycorrhizae: physiology and genetics. Paris: INRA, 1986. p.217-221.

VUOTTO, M.L.; BASILE, A.; MOSCATIELLO, V.; DE SOLE, P.; CASTALDO-COBIANCHI, R.; LAGHI, L.; IELPO, M.T.L. Antimicrobial and antioxidant activities of Feijoa sellowiana fruit. International Journal of Antimicrobial Agents, v.13, p.197-201, 2000. DOI: 10.1016/S0924-8579(99)00122-3.

Received on April 22, 2015 and accepted on May 25, 2016

Pesq. agropec. bras., Brasília, v.51, n.8, p.942-949, ago. 2016 DOI: $10.1590 / \mathrm{S} 0100-204 \mathrm{X} 2016000800006$ 